\title{
Staphylococcal cassette chromosome mec elements from Staphylococcus intermedius group (SIG) isolates from dogs in a center for veterinary diagnostics in Brazil
}

\author{
Regina Ruiz ${ }^{1}$ (D) Valcilaine Teixeira Barbosa ${ }^{2}$ (D) Teresa de Lisieux Guedes Ferreira Lôbo ${ }^{2}$ (D) \\ Rafael Aleixo dos Santos Silva ${ }^{2}$ (D) Rodrigo José Nunes Calumby ${ }^{2}$ (D) Suzanne Pinheiro Vieira ${ }^{2}$ (D) \\ Diogo Brandão ${ }^{3}$ (i) Felipe Mendes Zorzi ${ }^{4}$ (i) Rossana Teotônio de Farias Moreira ${ }^{5}$ (i) Valter Alvino (i) $^{2}$ \\ Ticiano Gomes do Nascimento ${ }^{2}$ (D) Luciano Aparecido Meireles Grilo ${ }^{2}$ (D) Camila Braga Dornelas $^{2}$ (i) \\ Elsa Masae Mamizuka ${ }^{1}$ (i) Lara Mendes de Almeida ${ }^{* * 2}$ (D)
}

\author{
${ }^{1}$ Faculdade de Ciências Farmacêuticas (FCF), Universidade de São Paulo (USP), 05508-000, São Paulo, SP, Brasil. E-mail: larameal@gmail.com. \\ ${ }^{*}$ Corresponding author. \\ ${ }^{2}$ Instituto de Ciências Farmacêuticas (ICF), Universidade Federal de Alagoas (UFAL), Maceió, AL, Brasil. \\ ${ }^{3}$ Instituto de Ciências Biológicas e da Saúde (ICBS), Universidade Federal de Alagoas (UFAL), Maceió, AL, Brasil. \\ ${ }^{4}$ Faculdade de Medicina Veterinária e Zootecnia (FMVZ), Universidade de São Paulo (USP), São Paulo, SP, Brasil. \\ ${ }^{5}$ Escola de Enfermagem (EENF), Universidade Federal de Alagoas (UFAL), Maceió, AL, Brasil.
}

\begin{abstract}
Methicillin resistance in the Staphylococcus intermedius group (SIG) has emerged in small animal practice. Methicillinresistant SIG (MRSIG) members have been implicated as causes of infections in both companion animals and humans. Staphylococcal cassette chromosome mec (SCCmec) elements carry the mecA/C genes, which encode for the transpeptidase PBP2a (PBP2') responsible for $\beta$-lactam antibiotic resistance in staphylococci. This study examined the SCCmec types of MRSIG isolates from different clinical specimens of dogs that exhibited methicillin MIC $\geq 0.5 \mu \mathrm{g} / \mathrm{mL}$ by an automated identification and susceptibility system in a Center for Veterinary Diagnostics in São Paulo, Brazil. Susceptibility to methicillin was determined by broth microdilution testing, and Oxoid ${ }^{\circledR}$ M.I.C.Evaluator ${ }^{\circledR}$ strips. PBP2a production was detected using a latex agglutination assay. SCCmec typing was performed according to the International Working Group on the Classification of Staphylococcal Cassette Chromosome Elements (IWG-SCC) guidelines. SCCmec type II (2A), SCCmec type III (3A), composite SCC structures consisting of a class A mec gene complex in addition to multiple ccr gene complexes, and non-typable SCCmec elements were reported in these MRSIG isolates. SCCmec type variants differing from those so far acknowledged by IWG-SCC were found, indicating new rearrangements in the genetic context of mecA in these canine MRSIG isolates.
\end{abstract}

Key words: Staphylococcus intermedius group (SIG), methicillin resistance, SCCmec elements, companion animals.

Cassetes cromossômicos estafilocócicos mec de isolados do grupo Staphylococcus intermedius (GSI) de cães em um centro veterinário de diagnósticos no Brasil

RESUMO: A resistência à meticilina no grupo Staphylococcus intermedius (GSI) tem aumentado na clínica de pequenos animais. Membros GSI resistentes à meticilina (GSIRM) têm sido causas de infecções tanto em animais de companhia e humanos. Cassetes cromossômicos estafilocócicos mec (SCCmec) carregam os genes mecA/C, que codificam a transpeptidase PBP2a (PBP2') responsável pela resistência aos antibióticos $\beta$-lactâmicos em estafilococos. Nosso objetivo foi investigar os elementos SCCmec de GSIRM isolados de diferentes amostras clínicas de cães que exibiram CIM de meticilina $\geq 0,5 \mu \mathrm{g} / \mathrm{mL}$ por meio de um sistema automatizado em um Centro Veterinário de Diagnósticos em São Paulo, Brasil. A sensibilidade à meticilina foi determinada por meio do teste de microdiluição em caldo e fitas Oxoid ${ }^{\mathbb{R}}$ M.I.C.Evaluator ${ }^{\mathbb{E}}$. A produção de PBP2a foi detectada usando um ensaio de aglutinação de látex. A tipagem dos elementos SCCmec foi realizada de acordo com as diretrizes do International Working Group on the Classification of Staphylococcal Cassette Chromosome Elements (IWG-SCC). SCCmec tipo II (2A), SCCmec tipo III (3A), SCC compostos de um complexo mec de classe A com múltiplos complexos ccr, e elementos SCCmec não tipáveis foram encontrados nesses isolados GSIRM. Variantes que diferem dos elementos SCCmec reconhecidos até o momento pelo IWG-SCC foram encontradas, indicando novos rearranjos no contexto genético de mecA nesses isolados GSIRM caninos.

Palavras-chave: Grupo Staphylococcus intermedius (GSI), resistência à meticilina, SCCmec, animais de companhia.

The Staphylococcus intermedius group (SIG) includes Staphylococcus intermedius, Staphylococcus pseudintermedius, and Staphylococcus delphini, Gram-positive cocci well adapted to the skin and mucosal microbiomes of a variety of animal hosts (MURRAY et al., 2018; YARBROUGH et al., 2018). SIG isolates have emerged as leading causes of infection of the urinary 
and respiratory tracts, surgical wounds, ears and skin in companion animals, and have also been increasingly associated with non-bite-related injuries in humans (VAN DUIJKEREN et al., 2011; DAVIS et al., 2014; SOMAYAJI et al., 2016). Identification of coagulasepositive staphylococci by MALDI-TOF MS or molecular methods has reliably allowed SIG species differentiation that have since been underreported or commonly misidentified as Staphylococcus aureus by conventional methods in clinical microbiology laboratories. Antibiotic-resistant SIG infections have raised concern in both veterinary small-animal practice and humans, in particular methicillinresistant $S$. pseudintermedius (MRSP) infections. MRSP is an opportunistic pathogen responsible for pyoderma, otitis, and wound infections in pets, and its transmission between animals and humans has been well documented (VAN DUIJKEREN et al., 2011; BÖRJESSON et al., 2012; BARDIAU et al., 2013; COUTO et al., 2014; GRÖNTHAL et al., 2014; MACCARTHY et al., 2015; DUIM et al., 2016; FEßLER et al., 2018; WORTHING et al., 2018).

Methicillin resistance in staphylococci occurs due to expression of the penicillin binding protein PBP2a (PBP2'), a transpeptidase which shows a slow rate of acylation by $\beta$-lactam antibiotics (FISHOVITZ et al., 2014). PBP2a is encoded by the mecA or mecC genes that are carried by mobile staphylococcal cassette chromosome mec (SCCmec) elements (HIRAMATSU et al., 2013). The SCCmec typing has long been used for understanding the epidemiology of methicillin-resistant $S$. aureus (MRSA) and community-associated MRSA (CAMRSA) strains (CHAMBERS \& DELEO, 2009), and it has also been useful to investigate MRSP spread that now has emerged as a zoonotic pathogen (PERRETEN et al., 2013; QUITOCO et al., 2013; MACCARTHY et al., 2015; WORTHING et al., 2018).

SCCmec type assignment has been established by the International Working Group on the Classification of Staphylococcal Cassette Chromosome Elements (IWG-SCC), and it is based on a combination of the mec gene complex (mecA-C resistance genes, mecRl and $m e c I$ regulatory genes, and insertion sequences), and the $c c r$ gene complex (cassette chromosome recombinases ccr) (IGWSCC, 2009; HIRAMATSU et al., 2013). The only few SCCmec elements so far characterized in MRSP indicated an evolutionary diversification of SCCmec structure in certain clonal lineages. Understanding how the genetic context of the mec gene has evolved in SIG isolates is crucial for controlling methicillin resistance that is on the rise in veterinary and healthcare settings. Therefore, in this study we examined the methicillin resistance phenotype and SCCmec types of methicillin-resistant SIG (MRSIG) isolates from different clinical specimens of dogs from a Center for Veterinary Diagnostics in São Paulo, Brazil.

From January to May 2014, a total of 41 SIG isolates exhibiting resistance to methicillin by BD PHOENIX Automated Microbiology System (MIC $\geq 0.5 \mu \mathrm{g} / \mathrm{mL}$ ) were recovered from various canine specimens in a routine diagnostic laboratory in SP, Brazil (Table 1). Skin, eye and ear samples were obtained using sterile swabs, whilst urine and ascitic fluid samples were obtained by cystocentesis and abdominal puncture, respectively. Overnight cultures at $37{ }^{\circ} \mathrm{C}$ of these samples yielded colonies with a double zone of betahemolysis on blood agar ( $5 \%$ sheep blood), which were submitted to biochemical conventional methods used to differentiate coagulase-positive Staphylococcus species from $S$. aureus, such as the latex slide agglutination test (clumping factor/ protein A), the tube coagulase test, DNase production, PYR, and polymyxin B resistance (BECKER et al., 2015).

Susceptibility to methicillin was determined by broth microdilution method according to the guidelines of the Clinical and Laboratory Standards Institute - CLSI (2018). Oxacillin susceptibility breakpoints added to CLSI supplement M100 were used to predict mecA-mediated oxacillin resistance (CLSI, 2016). Oxacillin M.I.C. evaluator strips (M.I.C.E., Thermo Fisher Scientific, Basingstoke, UK) were also used for all MRSIG isolates. S. aureus subsp. aureus ATCC 29213 was used as a control for antimicrobial susceptibility testing. The product of $m e c A$ was detected using the PBP2a latex agglutination assay (Oxoid, Hampshire, United Kingdom) according to the manufacturer's instructions. S. aureus ATCC 29213 (methicillin susceptible, mecA negative), and MRSA N315 (methicillin resistant, $m e c A$ positive) were used as controls for PBP2a production.

DNA of the 41 MRSIG isolates was extracted using DNeasy blood and tissue kits (Qiagen, USA), with lysozyme $(50 \mathrm{mg} / \mathrm{ml})$ and lysostaphin $(10 \mathrm{mg} / \mathrm{ml})$ being added to the initial DNA extraction step. The SCCmec typing was performed according to the IWG-SCC guidelines. PCR assays to identify mec classes and $c c r$ types were performed using primer sets as previously described (KONDO et al., 2007; ITO et al., 2014). Then, SCCmec types were assigned based on a combination of the type of mec gene complex (A, B, C1 and $\mathrm{C} 2$ ) and the $c c r$ gene allotype (1 to 5). The MRSA reference strains NCTC 10442 (type I), N315 (type II), 85/2082 (type III), 
Table 1 - SCCmec elements identified in MRSIG isolates from clinical infections in dogs in Brazil.

Isolate Sample $\quad \begin{gathered}\text { Oxacillin } \\ \mathrm{MIC}(\mathrm{mg} / \mathrm{L}) \quad-1\end{gathered}$

\begin{tabular}{|c|c|c|c|c|c|c|c|c|c|c|c|c|c|}
\hline 1 & Skin & $<0.5$ & - & - & - & - & - & - & - & - & - & - & - \\
\hline 2 & Skin & $<0.5$ & - & - & - & - & - & - & - & - & - & - & - \\
\hline 4 & Skin & 0.5 & + & - & + & - & - & - & + & - & - & + & $\mathrm{II}(2 \mathrm{~A})+c c r C$ \\
\hline 5 & Skin & 256 & + & - & + & - & - & - & - & + & + & - & III/VIII \\
\hline 6 & Skin & $<0.5$ & - & - & - & - & - & - & - & - & - & - & - \\
\hline 7 & Skin & 0.5 & + & - & + & - & - & - & + & - & - & + & II $(2 \mathrm{~A})+c c r C$ \\
\hline 8 & Skin & 8 & + & - & + & - & - & - & + & - & - & + & II $(2 \mathrm{~A})+c c r C$ \\
\hline 9 & Skin & 1 & + & - & - & - & - & - & + & - & - & + & non-typable \\
\hline 10 & Skin & $<0.5$ & + & - & - & - & - & - & + & - & - & + & non-typable \\
\hline 11 & Skin & $>512$ & + & - & + & - & - & - & - & + & + & - & III/VIII \\
\hline 14 & Skin & 1 & + & - & - & - & - & - & + & - & - & + & non-typable \\
\hline 15 & Skin & $>512$ & + & - & + & - & - & - & - & + & + & - & III/VIII \\
\hline 16 & Skin & $<0.5$ & - & - & - & - & - & - & - & - & - & - & - \\
\hline 17 & Skin & $<0.5$ & + & - & + & - & - & - & + & - & - & + & $\mathrm{II}(2 \mathrm{~A})+c c r C$ \\
\hline 19 & Skin & $>512$ & + & - & + & - & - & - & - & + & + & - & III/VIII \\
\hline 21 & Skin & $>512$ & + & - & + & - & - & - & - & + & + & - & III/VIII \\
\hline 23 & Skin & 512 & + & - & + & - & - & - & - & + & - & - & III (3A) \\
\hline 24 & Skin & 256 & + & - & + & - & - & - & + & - & - & + & $\mathrm{II}(2 \mathrm{~A})+c c r C$ \\
\hline 25 & Skin & 512 & + & - & + & - & - & - & - & + & + & + & $\begin{array}{c}\mathrm{III} / \mathrm{VIII}+ \\
\operatorname{ccrC}\end{array}$ \\
\hline 26 & Skin & $>512$ & + & - & + & - & - & - & - & + & + & + & $\begin{array}{l}\mathrm{III} / \mathrm{VIII}+ \\
\quad c c r C\end{array}$ \\
\hline 31 & Skin & 256 & + & - & - & - & - & - & + & - & - & + & non-typable \\
\hline 32 & Skin & 256 & + & - & - & - & - & - & + & - & - & + & non-typable \\
\hline 33 & Skin & 128 & + & - & + & - & - & - & + & - & - & + & $\mathrm{II}(2 \mathrm{~A})+c c r C$ \\
\hline 34 & Skin & 512 & + & - & + & - & - & - & + & + & + & + & $\begin{array}{c}\mathrm{II} / \mathrm{III} / \mathrm{VIII}+ \\
\operatorname{ccr} C\end{array}$ \\
\hline 35 & Skin & 256 & + & - & - & - & - & - & + & - & - & + & non-typable \\
\hline 36 & Skin & 512 & + & - & + & - & - & - & + & + & - & - & II/III \\
\hline 37 & Skin & 512 & + & - & + & - & - & - & + & - & - & + & $\mathrm{II}(2 \mathrm{~A})+c c r C$ \\
\hline 38 & Skin & $>512$ & + & - & + & - & - & - & - & + & + & + & $\begin{array}{c}\mathrm{III} / \mathrm{VIII}+ \\
\quad c c r C\end{array}$ \\
\hline 39 & Skin & 64 & + & - & + & - & - & - & + & - & - & + & $\mathrm{II}(2 \mathrm{~A})+c c r C$ \\
\hline 40 & Skin & $>512$ & + & - & + & - & - & - & + & + & + & - & II/III/VIII \\
\hline 41 & Skin & $>512$ & + & - & + & - & - & - & + & + & - & + & $\mathrm{II} / \mathrm{III}+c c r C$ \\
\hline 12 & Ear & $>512$ & + & - & + & - & - & - & - & + & + & - & III/VIII \\
\hline 20 & Ear & 2 & + & - & + & - & - & - & + & - & - & + & $\mathrm{II}(2 \mathrm{~A})+c c r C$ \\
\hline 28 & Ear & 16 & + & - & + & - & - & - & + & + & - & + & $\mathrm{II} / \mathrm{III}+c c r C$ \\
\hline 29 & Ear & 256 & + & - & + & - & - & - & - & + & - & - & III (3A) \\
\hline 30 & Ear & 256 & + & - & + & - & - & - & - & + & + & - & III/VIII \\
\hline 13 & Urine & $<0.5$ & + & - & + & - & - & - & - & + & + & - & III/VIII \\
\hline 18 & Urine & $<0.5$ & - & - & - & - & - & - & - & - & - & - & - \\
\hline 27 & Urine & 256 & + & - & + & - & - & - & + & + & + & + & $\begin{array}{c}\mathrm{II} / \mathrm{III} / \mathrm{VIII}+ \\
\operatorname{ccr} C\end{array}$ \\
\hline 3 & $\begin{array}{l}\text { Ascitic } \\
\text { fluid }\end{array}$ & 0.5 & + & - & + & - & - & - & + & - & - & + & $\mathrm{II}(2 \mathrm{~A})+c c r C$ \\
\hline 22 & Eye & 512 & + & - & + & - & - & - & - & + & + & - & III/VIII \\
\hline
\end{tabular}

JCSC1978 (type IV), and MRSA clinical strains from our laboratory collection (types V, VI, VII and VIII) were used as controls. Sanger sequencing was previously carried out to confirm all PCR amplicons from the MRSA control strains.

The canine MRSIG isolates of this study were carriers of SCCmec type II (2A) (10/41),
SCCmec type III (3A) (2/41), and composite SCC structures consisting of a class A mec gene complex in addition to multiple $c c r$ gene complexes as follows: types 2 and $3(1 / 41)$; types 2, 3, and $4(1 / 41)$; types 2 , 3 , and $5(2 / 41)$; types $2,3,4$, and $5(2 / 41)$; types 3 and $4(9 / 41)$ and types 3,4 , and $5(3 / 41)$. mecA-positive MRSIG isolates carrying non-typable SCCmec 
elements were also reported (6/41). These SCCmec elements consisted of $\mathrm{ccr}$ gene complexes types 2 and 5 , but classes of mec gene complex (A, B, C1 and $\mathrm{C} 2$ ) could not be identified using the primer sets described by KONDO et al. (2007) and Ito et al. (2014) (Table 1). Composite SCC structures have been reported by carrying an association of a mec gene complex with two or more $c c r$ gene allotypes, which may result from deletions of the original J region or insertions of other IS elements (CHANCHAITHONG et al., 2015). Genetic organization of the new composite SCC structures, such as SCCmec II-III, SCCmec VII-241, SCCmec $\mathrm{V}$, $\psi \mathrm{SCC}$ mec57395, SCCmec IVg, SCCmec VT, and SCCmecKW21 has been characterized in MRSP, and consist of unusual combinations of mec gene complexes with $c c r$ gene complexes (DESCLOUX et al., 2008; BLACK et al., 2009; SHORE et al., 2011; PERRETEN et al., 2013; CHANCHAITHONG et al., 2015; WU et al., 2015; DUIM et al., 2018).

All MRSIG isolates harboring SCCmec type II (2A) also carried a $c c r C$ gene, in addition to the $c c r A 2 B 2$ gene, but the class A mec gene complex was disrupted in five of these $\mathrm{SCCmec}$ elements. The primer set constructed on mecA and mecI produced a PCR amplicon smaller than the expected size. Then, other primers to amplify internal fragments of $m e c A$ and its regulatory genes mecRl and mecI were used indicating that mecRl was disrupted. Class A mec is considered the prototype complex that contains the mecA regulatory locus. Disruption of the signal transducer protein MecR1 did not affect the mecA expression, as high oxacillin MIC levels (128 - 512 $\mu \mathrm{g} / \mathrm{mL}$ ) were exhibited by most of these isolates. Transcriptional repressor MecI proteolysis, which was shown to be dependent on MecR2 instead of MecR1 (ARÊDE \& OLIVEIRA, 2013), is essential for the expression of $\beta$-lactam resistance. The MRSIG isolates that carried a SCCmec type II (2A) with an intact class A mec gene complex instead showed lower oxacillin MIC's values $(<0,5-2 \mu \mathrm{g} / \mathrm{mL})$. The non-typable SCCmec elements had the same association of $c \mathrm{cr}$ genes ( $c \mathrm{cr} C$ and $c \mathrm{crA2B2}$ ) as seen in SCCmec type II (2A), but lacked a mec gene complex structurally organized as in the classes A, B, C1 or $\mathrm{C} 2$. The wide variation in susceptibility to oxacillin (MIC's $<0,5-256 \mu \mathrm{g} / \mathrm{mL}$ ) demonstrated by these isolates might be derived from new rearrangements of the $m e c A$-regulatory genes. MRSIG isolates carrying a SCCmec type III (3A) or SCCmec composites exhibited high oxacillin resistance (MIC's ranging from 256 to $\geq 512 \mu \mathrm{g} / \mathrm{mL}$ ).

Heterogeneous oxacillin resistance could be detected in an SCCmec composite-carrying MRSIG isolate from urine. The mecA-positive MRSIG isolate 36 exhibited an oxacillin MIC $<0,5 \mu \mathrm{g} / \mathrm{mL}$ by broth microdilution testing, but subpopulations of highly resistant cells (MIC $\geq 256 \mu \mathrm{g} / \mathrm{mL}$ ) from the MRSIG 36 culture could be identified using a M.I.C. Evaluator strip (M.I.C.E., Thermo Fisher Scientific, Basingstoke, UK). Most clinical isolates of mecApositive staphylococci express a heterogeneous oxacillin phenotype, in which most cells exhibit lowlevel oxacillin resistance while subpopulations are able to express higher oxacillin resistance levels. Heteroresistant MRSIG isolates might be unrecognized by automated identification and susceptibility systems or conventional antimicrobial susceptibility testing in clinical laboratories, leading to $\beta$-lactam therapy failures. BD PHOENIX Automated Microbiology System predicted an oxacillin MIC $\geq 0.5 \mu \mathrm{g} / \mathrm{mL}$ for MRSIG 36, but it could not reliably determine susceptibility to methicillin in other five mecAnegative MRSIG isolates, which exhibited $\mathrm{MIC}<0,5$ $\mu \mathrm{g} / \mathrm{mL}$ using the oxacillin broth microdilution test.

PBP2a latex agglutination testing yielded weak positive results for the oxacillin-heteroresistant isolate 36 and all MRSIG isolates with SCCmec type II (2A) or non-typable SCCmec elements, while stronger positive reactions were observed for MRSIG isolates with SCCmec type III (3A) or SCCmec composites. No correlation between the direct $\mathrm{PBP} 2 \mathrm{a}$ test results and the oxacillin MIC values was observed.

Further investigation must be performed to characterize the $\mathrm{SCCmec}$ type variants found in these canine MRSIG isolates from various clinical infections, but PCR-based SCCmec typing could indicate the formation of genetic contexts enabling horizontal transfer of $m e c A$ that differ from those so far acknowledged as new for SIG by IWG-SCC. Methicillin resistance in staphylococcal species from companion animals raises concern, as $\beta$-lactams are veterinary critically important antimicrobials, and SIG isolates have the potential for zoonotic infections.

\section{ACKNOWLEDGEMENTS}

This project was funded by Conselho Nacional de Desenvolvimento Científico e Tecnológico (CNPq), Fundação de Amparo à Pesquisa do Estado de São Paulo (FAPESP), Brazil, and was financed in part by the Coordenação de Aperfeiçoamento de Pessoal de Nível Superior (CAPES), Brasil - Finance code 001.

\section{DECLARTION OF CONFLICT OF INTEREST}

The authors declare no conflict of interest. The founding sponsors had no role in the design of the study; in the 
collection, analyses, or interpretation of data; in the writing of the manuscript, and in the decision to publish the results.

\section{AUTHORS' CONTRIBUTIONS}

RR performed the sample collection, bacterial isolation, antimicrobial susceptibility testing and PCR assays with collaboration of VTB, TLGFL, RASS, RJNC, SPV, DB and FZ. EMM and LMA planned the study and wrote the paper with collaboration of RTFM, VA, TGN, LAMG and CBD.

\section{REFERENCES}

ARÊDE, P.; OLIVEIRA, D. C. Proteolysis of mecA repressor is essential for expression of methicillin resistance by Staphylococcus aureus. Antimicrobial Agents and Chemotherapy, v.57, n.4, p.20012002, 2013. Available from: <https://doi.org/10.1128/AAC.0251012>. Accessed: Sep. 19, 2020. doi: 10.1128/AAC.02510-12.

BARDIAU, M. et al. Characterization of methicillin-resistant Staphylococcus pseudintermedius isolated from dogs and cats. Microbiology and Immunology, v.57, n.7, p.496-501, 2013. Available from: <https://doi.org/10.1111/1348-0421.12059>. Accessed: Aug. 28, 2020. doi: 10.1111/1348-0421.12059.

BECKER, K. et al. Staphylococcus, Micrococcus, and other catalase-positive cocci. In: Jorgensen JH, Carroll KC, Funke G, Pfaller MA. Manual of clinical microbiology, 11 th ed. Washington: ASM Press; 2015. 354-382.

BLACK, C. C. et al. Identification of a predominant multilocus sequence type, pulsed- field gel electrophoresis cluster, and novel staphylococcal chromosomal cassette in clinical isolates of mecAcontaining, methicillin-resistant Staphylococcus pseudintermedius. Veterinary Microbiology, v.139, n.3-4, p. 333-338, 2009. Available from: <https://doi.org/10.1016/j.vetmic.2009.06.029>. Accessed: Sep. 26, 2020. doi: 10.1016/j.vetmic.2009.06.029.

BÖRJESSON, S. et al. Methicillin-resistant Staphylococcus pseudintermedius in Sweden. Microbial Drug Resistance, v.18, n.6, p.597-603, 2012. Available from: <https://doi.org/10.1089/ mdr.2012.0069>. Accessed: Sep. 03, 2020. doi: 10.1089/ mdr.2012.0069.

CHAMBERS, H. F.; DELEO, F. R. Waves of resistance: Staphylococcus aureus in the antibiotic era. Nature Reviews Microbiology, v.7, n.9, p.629-641, 2009. Available from: $<$ https:// doi.org/10.1038/nrmicro2200>. Accessed: Aug. 26, 2020. doi: $10.1038 /$ nrmicro 2200 .

CHANCHAITHONG, P. et al. Characterization of a novel composite staphylococcal cassette chromosome mec in methicillinresistant Staphylococcus pseudintermedius from Thailand. Antimicrobial Agents and Chemotherapy, v.60, n.2, p.11531157, 2015. Available from: <https://doi.org/10.1128/AAC.0016506>. Accessed: Sep. 20, 2020. doi: 10.1128/AAC.00165-06

CLSI - Clinical and Laboratory Standards Institute. Performance standards for antimicrobial disk and dilution susceptibility tests for bacteria isolated from animals; Approved Standard, CLSI document VET08 4th ed. Wayne PA, USA, 2018.

CLSI - Performance standards for antimicrobial susceptibility testing. Document M100. Clinical and Laboratory Standards Institute, Wayne PA, USA, 2016.
COUTO, N. et al. Genetic relatedness, antimicrobial and biocide susceptibility comparative analysis of methicillin-resistant and -susceptible Staphylococcus pseudintermedius from Portugal. Microbial Drug Resistance, v. 20, n. 4, p. 364-371, 2014. Available from: <https://doi.org/10.1089/mdr.2013.0043>. Accessed: Aug. 03, 2020. doi: 10.1089/mdr.2013.0043.

DAVIS, J. A. et al. Carriage of methicillin-resistant staphylococci by healthy companion animals in the US. Letters in Applied Microbiology, v.59, n.1, p.1-8, 2014. Available from: $<$ https://doi. org/10.1111/lam.12254>. Accessed: Sep. 11, 2020. doi: 10.1111/ lam. 12254 .

DESCLOUX, S. et al. Characterization of new Staphylococcal Cassette Chromosome mec ( $\mathrm{SCCmec}$ ) and topoisomerase genes in fluoroquinolone- and methicillin-resistant Staphylococcus pseudintermedius. Journal of Clinical Microbiology, v.46, n.5, p.1818-1823, 2008. Available from: <https://doi.org/10.1128/ JCM.02255-07>. Accessed: Sep. 16, 2020. doi: 10.1128/ JCM.02255-07.

DUIM, B. et al. Changes in the population of methicillinresistant Staphylococcus pseudintermedius and dissemination of antimicrobial-resistant phenotypes in the Netherlands. Journal of Clinical Microbiology, v.54, n.2, p.283-288, 2016. Available from: < https://doi.org/10.1128/JCM.01288-15>. Accessed: Sep. 01, 2020. doi: 10.1128/JCM.01288-15.

DUIM, B. et al. Methicillin-resistant Staphylococcus pseudintermedius among dogs in the description of novel SCCmec variants. Veterinary Microbiology, v.213, p.136-141, 2018. Available from: <https://doi.org/10.1016/j.vetmic.2017.11.022>. Accessed: Sep. 22, 2020. doi: 10.1016/j.vetmic.2017.11.022.

FEßLER, A. T. et al. Methicillin-resistant Staphylococcus aureus (MRSA) and methicillin-resistant Staphylococcus pseudintermedius (MRSP) among employees and in the environment of a small animal hospital. Veterinary Microbiology, v.221, p.153-158, 2018. Available from: $<$ https://doi.org/10.1016/j. vetmic.2018.06.001>. Accessed: Aug. 26, 2020. doi: 10.1016/j. vetmic.2018.06.001.

FISHOVITZ, J. et al. Penicillin-binding protein 2a of methicillinresistant Staphylococcus aureus. IUBMB Life, v.66, n.8, p.572577, 2014. Available from: <https://doi.org/10.1002/iub.1289>. Accessed: Aug. 16, 2020. doi: 10.1002/iub.1289.

GRÖNTHAL, T. et al. Large outbreak caused by methicillin resistant Staphylococcus pseudintermedius ST71 in a Finnish veterinary teaching Hospital - from outbreak control to outbreak prevention. PLoS One, v.9, n.10, p.1-11, 2014. Available from: $<$ https://doi.org/10.1371/journal.pone.0110084>. Accessed: Aug. 27, 2020. doi: 10.1371/journal.pone.0110084.

HIRAMATSU, K. et al. Genomic basis for methicillin resistance in Staphylococcus aureus. Infection \& Chemotherapy, v.45, n.2, p.117-136, 2013. Available from: <https://doi.org/10.3947/ ic.2013.45.2.117>. Accessed: Aug. 24, 2020. doi: 10.3947/ ic. 2013.45.2.117.

INTERNATIONAL WORKING GROUP ON THE CLASSIFICATION OF STAPHYLOCOCCAL CASSETTE CHROMOSOME ELEMENTS (IWG-SCC). Classification of staphylococcal cassette chromosome mec ( $\mathrm{SCCmec}$ ): guidelines for reporting novel SCCmec elements. Antimicrobial Agents and Chemotherapy, v.53, n.12, p.4961-4967, 2009. Available from: 
$<$ https://doi.org/10.1128/AAC.00579-09>. Accessed: Aug. 26, 2020. doi: 10.1128/AAC.00579-09.

ITO, T. et al. Staphylococcal cassette chromosome mec (SCCmec) analysis of MRSA. Methods in Molecular Biology, v. 1085, p. 131148, 2014. Available from: <https://doi.org/10.1007/978-1-62703-6641 8>. Accessed: Aug. 23, 2020. doi: 10.1007/978-1-62703-664-1 8.

KONDO, Y.etal. Combination of multiplex PCRs for staphylococcal cassette chromosome mec type assignment: rapid identification system for $m e c, c c r$, and major differences in junkyard regions. Antimicrobial Agents and Chemotherapy, v.51, n.1, p.264-274, 2007. Available from: <https://doi.org/10.1128/AAC.00165-06>. Accessed: Aug. 26, 2020. doi: 10.1128/AAC.00165-06.

MACCARTHY, A. J. et al. Genomic insights into the rapid emergence and evolution of MDR in Staphylococcus pseudintermedius. Journal of Antimicrobial Chemotherapy, v.70, n.4, p.997-1007, 2015 Available from: <https://doi.org/10.1093/jac/dku496>. Accessed: Aug. 26, 2020. doi: 10.1093/jac/dku496.

MURRAY, A. K. et al. Staphylococcus cornubiensis sp. nov., a member of the Staphylococcus intermedius group (sig). International Journal of Systematic and Evolutionary Microbiology, v.68, n.11, p.3404-3408, 2018. Available from: $<$ https://doi.org/10.1099/ijsem.0.002992>. Accessed: Sep. 12, 2020. doi: 10.1099/ijsem.0.002992.

PERRETEN, V. et al. Novel pseudo-staphylococcal cassette chromosome mec element ( $\left.\psi \mathrm{SCCmec}_{57395}\right)$ in methicillin-resistant Staphylococcus pseudintermedius CC45. Antimicrobial Agents and Chemotherapy, v.57, n.11, p.5509-5515, 2013. Available from: <https://doi.org/10.1128/AAC.00738-13>. Accessed: Aug. 14, 2020. doi: 10.1128/AAC.00738-13.

QUITOCO, I. M. et al. First report in south America of companion animal colonization by the USA1100 clone of communityacquired meticillin-resistant Staphylococcus aureus (ST30) and by the european clone of methicillin-resistant Staphylococcus pseudintermedius (ST71). BMC Research Notes, v.6, n.336, p.17, 2013. Available from: <https://doi.org/10.1186/1756-0500-6336>. Accessed: Aug. 17, 2020. doi: 10.1186/1756-0500-6-336.
SHORE, A. C. et al. Detection of staphylococcal cassette chromosome mec type XI carrying highly divergent mecA, $m e c I, m e c R 1, b l a Z$, and $c c r$ genes in human clinical isolates of clonal complex 130 methicillin-resistant Staphylococcus aureus. Antimicrobial Agents and Chemotherapy, v.55, n.8, p.37653773, 2011. Available from: <https://doi.org/10.1128/AAC.0018711>. Accessed: Sep. 27, 2020. doi: 10.1128/AAC.00187-11.

SOMAYAJI, R. et al. Human infections due to Staphylococcus pseudintermedius, an emerging zoonosis of canine origin: report of 24 cases. Diagnostic Microbiology and Infectious Disease, v.85, n.4, p.471-476, 2016. Available from: <https://doi.org/10.1016/j. diagmicrobio.2016.05.008>. Accessed: Aug. 27, 2020. doi: 10.1016/j.diagmicrobio.2016.05.008.

VAN DUIJKEREN, E. et al. Transmission of methicillin-resistant Staphylococcus pseudintermedius between infected dogs and cats and contact pets, humans and the environment in households and veterinary clinics. Veterinary Microbiology, v.150, n.34, p.338-343, 2011. Available from: <https://doi.org/10.1016/j. vetmic.2011.02.012>. Accessed: Aug. 30, 2020. doi: 10.1016/j. vetmic.2011.02.012.

WORTHING, K. A. et al. Characterization of staphylococcal cassette chromosome mec elements from methicillin-resistant Staphylococcus pseudintermedius infections in Australian animals. mSphere, v.3, n.6, p.1-7, 2018. Available from: <https://doi. org/10.1128/mSphere.00491-18>. Accessed: Sep. 01, 2020. doi: 10.1128/mSphere.00491-18.

WU, Z. et al. Novel type XII Staphylococcal cassette chromosome mec harboring a new cassette chromosome recombinase, CcrC2. Antimicrobial Agents and Chemotherapy, v. 59, n. 12, p. 7597 7601, 2015. Available from: $<$ https://doi.org/ 10.1128/AAC.0169215>. Accessed: Set. 18, 2020. doi: 10.1128/AAC.01692-15.

YARBROUGH, M. L. et al. Epidemiology, clinical characteristics, and antimicrobial susceptibility profiles of human clinical isolates of Staphylococcus intermedius group. Journal of Clinical Microbiology, v.56, n.3, p.01-10, 2018. Available from: <https:// doi.org/10.1128/JCM.01788-17>. Accessed: Sep. 15, 2020. doi: 10.1128/JCM.01788-17. 